\title{
E-Upakara, Bebantenan Learning Information System with Tree Diagram Model
}

\author{
Oka Sudana ${ }^{1}$, I Dewa Nyoman Nurweda Putra ${ }^{2}$, Ayu Wirdiani ${ }^{3}$, Dewa Ayu \\ Nadia Taradhita ${ }^{4}$
}

\author{
${ }^{1,3,4}$ Information Technology Department, Faculty of Engineering, \\ Universitas Udayana, Indonesia \\ ${ }^{2}$ Marine Science Department, Faculty of Marine Science and Fisheries,
} Universitas Udayana, Indonesia

Email: ${ }^{1}$ agungokas@unud.ac.id, ${ }^{2}$ nurweda14@unud.ac.id, ${ }^{3}$ ayuwirdiani@unud.ac.id, ${ }^{4}$ taradhita@ gmail.com

\begin{abstract}
Yadnya ceremony is a religious ceremony when Hindus expressed gratitude to God, to fellow humans, to the rest, (priest/teacher), to the ancestors, and to Bhuta Kala. The implementation of Yadnya is usually accompanied by bebantenan (offerings) or upakara. Nowadays there are many Hindus especially the younger generation who do not understand about bebantenan and Yadnya ceremony, because information about bebantenan and Yadnya ceremony is relatively difficult to obtain. E-Upakara system or Bebantenan Information System as a part of EUpacaraYadnya System is made to help people learning about bebantenan. Te tree diagram model is used to illustrate the relations between bebantenan and Yadnya. E-Upakara provides information related to Yadnya ceremonies such as the time the ceremony is held, the ceremony procedures, the bebantenan used during the ceremony, procedures of making bebantenan, videos, and pictures of banten. From test results, E-Upakara can be accessed with multiple platforms and easily provides information about related upakara used in specific Yadnya ceremony.
\end{abstract}

Keywords: E-UpacaraYadnya, E-Upakara, Bebantenan System, web and mobile programming, tree diagram model.

\section{INTRODUCTION}

Researches on the implementation of information technology in Balinese culture and Hindu religion are still relatively rare, especially the ones related to Yadnya ceremonies, bebantenan, kekidungan yadnya, mantram, and dances related to yadnya. In contrast with the assumption that information technology is something that is very modern, local culture such as Balinese culture and Hindu religion whose followers are relatively few is often perceived as "old fashioned", causing the lack of interest from Balinese people to combine these two [1].

Yadnya ceremony in Hinduism holds a very important position. The ceremony is a form of religious activity, which is in the form of human activities to strengthen their inner feelings in getting closer to God, to express gratitude, ask for guidance, forgiveness and salvation. The ceremony is accompanied by bebantenan (offerings) or upakara. Nowadays the form of upakara or bebantenan is very diverse, apart from many functions and usage, the variety of upakara or bebantenan is also influenced by the culture and art of local area [2,3]. 
Hindus in Bali should be able to understand which bebantenan is needed in a religious ceremony, because of the widespread use of bebantenan or upakara in Bali. The understanding of bebantenan is not only intended to increase knowledge alone, but can also influence efforts to preserve the culture of Bali. Bebantenan needs to be preserved because today there are so many Hindus, especially the younger generation who lack understanding about upakara or bebantenan due to their complexity. One of the reasons why Hindus are reluctant to make banten by themselves is because they don't know which banten is used for each ceremony. This is because information about bebantenan is still very limited and hard to obtain [4].

One way to help overcoming the problems of understanding religious ceremonies and bebantenan is by the development of an information system that gives information related to Yadnya ceremony, which is multimedia-based and can be implemented in either web or Android platform. The existing information systems of bebantenan related to Yadnya ceremony [5,6] and according to types of banten [7] already provided information about the making of bebantenan for Hindu ceremonies. However, the videos and photos in both systems were ordinary photos and videos that are less appealing to young people to learn. A web-based Pitra Yadnya information system [3] has the same problem with existing Yadnya information systems, where it's still not integrated between one information system with another. Web-based Bebayuhan Oton information system gave the information about the process of Bayuh Oton ceremony with the necessary banten used, however it still uses only photos and text captions [8]. Tree data structure has been used for modelling on making Android based information systems about Yadnya ceremony [9], as well as Ulam Bebantenan [10]. The learning media for making upakara for the Nyiramin Layon procession is designed based on Android by displaying 3-dimensional objects, photos and videos [11]. An Android application using 3-dimensional objects has been developed as a learning medium for Mendem Ari-ari ceremony process [12]. Augmented Realitybased application aimed at learning to make Banten Otonan has been developed with detailed animations for the making of banten (Sampian) items [13].

This paper proposes an E-Upakara information system, which is an information system that provides information about bebantenan in Yadnya ceremony. E-Upakara is a part of E-Upacara Yadnya application, which is equipped with multimedia such as photos, videos and animations. This paper is arranged as follows. Section 2 describes the methods used. Section 3 discusses the testing result of E-Upakara information system. Lastly, Section 4 discusses the conclusion taken from the testing result.

\section{METHODS}

\subsection{Yadnya}

The word yadnya is a Sanskrit language word rooted in the word yaj, which means "praying". The word yaj eventually developed into yadnya meaning offerings. Yadnya is all actions that are based on dharma (good deeds) and are done sincerely [2]. Yadnya consists of five categories (Panca Yadnya) which are described as follows.

1) Dewa Yadnya is a sincere offering to Hyang Widhi as an expression of gratitude for his gift of giving life and life to humans. 
2) Pitra Yadnya is an offering to the ancestors as an expression of gratitude for their services in giving birth, raising and maintaining life in the world so that we can become an independent person.

3) Rsi Yadnya is a Yadnya to the Rsi or Sulinggih (priest) for their services in guiding the people in religious life and as a person who has the duties in completing religious ceremonies.

4) Manusa Yadnya serves both as ceremonies of celebrating life cycle of a human and as the Yadnya intended to help fellow humans.

5) Bhuta Yadnya is a sacred sacrifice to Bhuta Kala to keep the balance between bhuwana agung (macrocosms/the universe) and bhuwana alit (microcosmos/our world).

\subsection{Upakara and Bebantenan}

Upakara is a means or equipment used in a ceremony [2]. Upakara in general is made of leaves, flowers, fruits, and water in various ways of processing. Upakara in Bali is known as banten that has similar meaning with upakara. The word banten implies to awake the presence of memories towards Hyang Widhi because he is the creator of this world [10].

\subsection{System Architecture Design}

The E-Upakara system architecture design involves the user (who manages both user data and bebantenan data within the web site) and the guest (who can retrieve the bebantenan information) as shown in Figure 2.

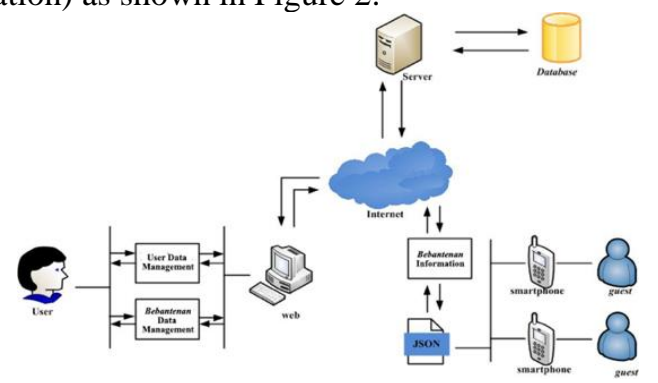

Figure 1. E-Upakara information system architecture design

\subsection{Tree Diagram Modelling}

The Tree diagram is used to describe the general framework of banten/upacara information system. Tree diagram usually describes the hierarchy of relations from each element [1]. This modelling is done to understand the relations between one ceremony with another and the bebantenan used. Yadnya ceremony consists of ceremony group, description, time of execution, level of ceremony, place of execution, peтирut (the leader of ceremony process), the ceremony procedures, means of ceremony, video, and pictures of ceremony as described in Figure 3.

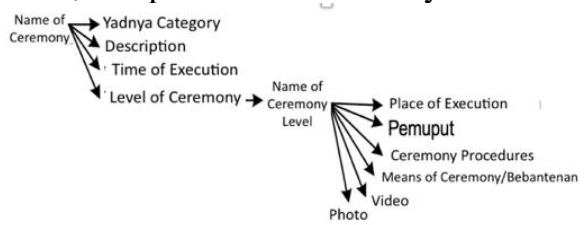


Figure 2. General modelling of yadnya ceremony related to bebantenan

The Yadnya ceremony group describes which group from Panca Yadnya the ceremony belongs to. The E-Upakara Information System Tree Diagram is presented in three categories, which are the relations of banten/upakara with Panca Yadnya, the tree diagram of the banten/upakara and their equipment, and the tree diagram of one of the banten/upakara namely Banten Ajuman/Soda.

\subsubsection{Tree Diagram of Banten/Upakara Based on Its Properties}

The tree diagram of upakara/banten has two properties which are the detail of upakara and the usage of upakara. The detail of upakara is then divided into upakara description and function, upakara equipments, photos of upakara, steps of making upakara, and video tutorial on how to make upakara. The usage of upakara consists of ceremony name and name of upakara. Based on the research conducted, the tree diagram of banten/upakara based on its properties can be illustrated as shown in Figure 4.

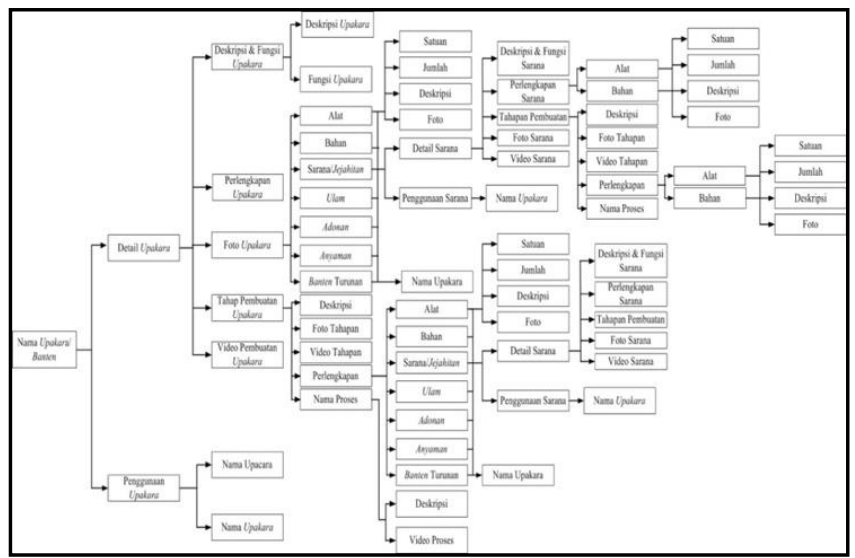

Figure 3. Tree diagram of banten and its properties

\subsubsection{Tree Diagram of Banten/Upakara Related to Yadnya Ceremony}

The relationship between upakara/banten and Yadnya ceremony is shown by tendencies of upakara/banten from each Yadnya ceremony to be different. Sometimes the procession of Yadnya ceremony isn't held in only one place, but can be held in multiple places. Figure 5 shows the tree diagram of upakara/banten related to Yadnya ceremony. 


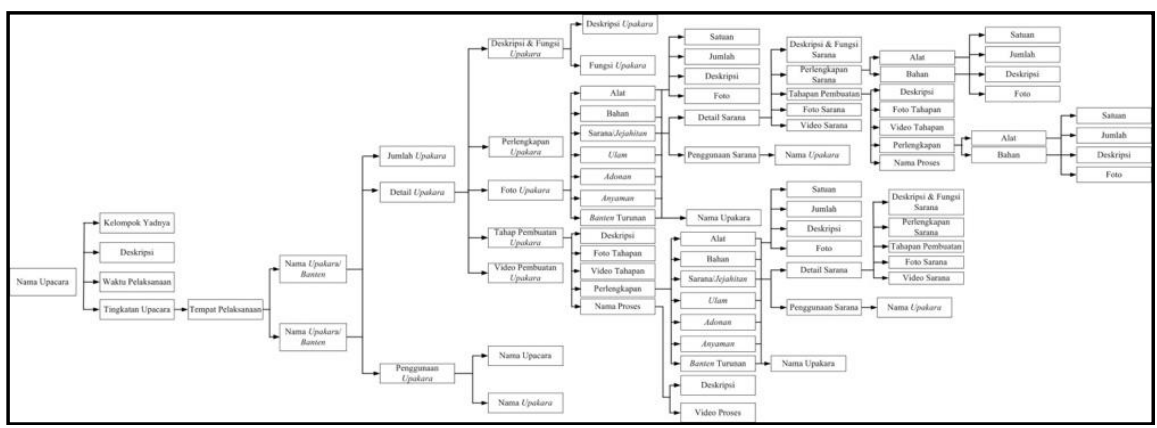

Figure 4. Tree diagram of yadnya ceremony related to bebantenan

\subsubsection{Tree Diagram of Banten Ajuman/Sodan}

Banten Ajuman/Sodan is one of the upakara used when tangkil (coming) to Pura or become part of other bebantenan. Figure 6 shows tree diagram of Banten Ajuman/Sodan

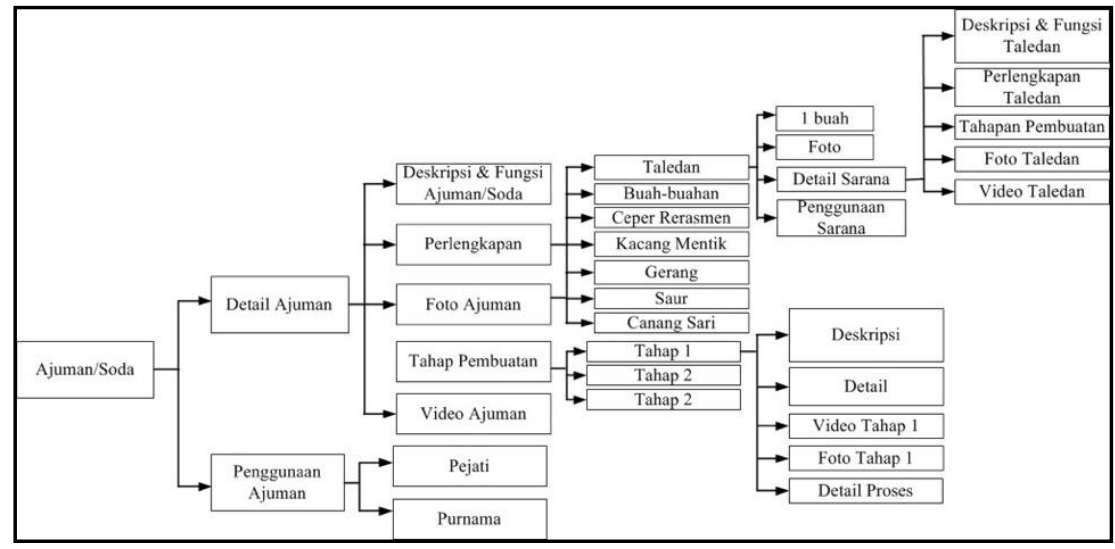

Figure 5. General modelling of yadnya ceremony related to bebantenan

Figure 5 displays the tree diagram of Banten Ajuman/Soda. Banten Ajuman/Soda will be divided into two properties which are Banten Detail and Banten Usage. Banten Detail consists of description, function, equipments, photos, the stages of making, and videos of making banten. The Banten equipments show the ingredients that make up the banten, which are tools, ingredients, ulam, dough, anyaman (matting), jejaritan, and banten turunan. Each equipment will contain the number of equipment needed, the display photo of the equipment and unit. Details about equipment can also be explained. The stages of making bebantenan is explained in the form of a description accompanied by detailed equipment used at that stage, photos, videos and an explanation of the process. The Banten Usage part explains where Banten Ajuman/Soda is used in banten or ceremony, which is in Banten Pejati during the the Purnama ceremony.

\subsection{Context Diagram}


Context diagram illustrates all the relations of the main entities involved inside the information system [8]. Figure 6 shows the context diagram of bebantenan information system.

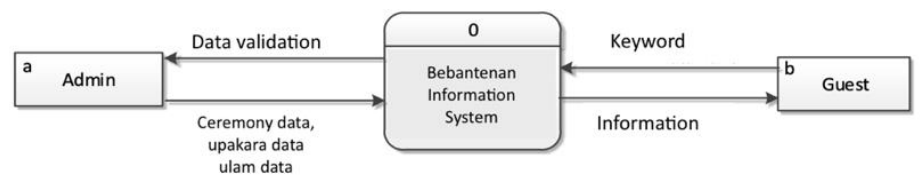

Figure 6. Context diagram of E-Upakara System

The context diagram as shown in Figure 6 has two entities, namely guest and admin. The admin entity is able to input data (such as ceremony data, upakara data, and ulam data) and validate data from the system. The guest entity can find the bebantenan information by inputting the keyword to the information system, and accesses bebantenan information.

\section{RESULT AND DISCUSSION}

A web-based E-Upakara information system was built with CodeIgniter 3. The ceremony, upakara, and ulam data used for creating the information system were obtained from Ida Sulinggih (Hindu religious leaders), traditional elders who understand about religious ceremony, Banten makers, and places where Yadnya ceremony is held. The data is then stored inside the database, where the CRUD process is able to change the existed data. E-Upakara system testing includes data input that is only done by the administrator and feature testing.

In order to access the dashboard page, the administrator must be logged in first. The user interface of dashboard page is shown in Figure 7.

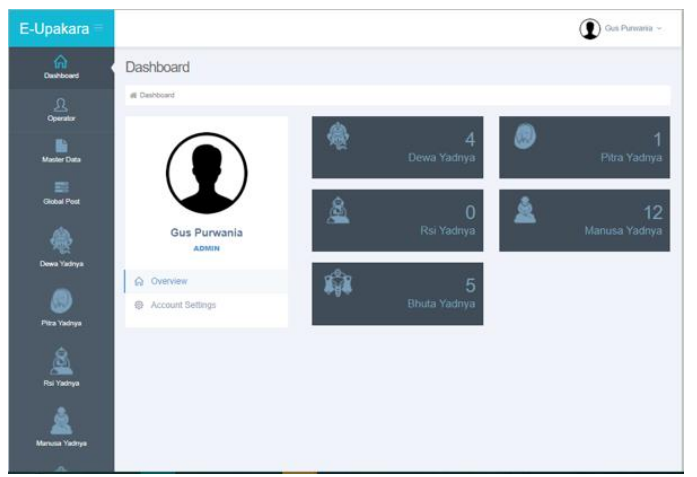

Figure 7. User interface of E-Upakara dashboard page

Master data management is a feature available for administrator in E-Upakara information system. Administrators have full access rights in master data management. The usage of master data is to add Yadnya category and post type. The Master Data functions to add categories from the Panca Yadnya such as Dewa Yadnya, Pitra Yadnya, Rsi Yadnya, Manusa Yadnya, and Bhuta Yadnya. Post type is a 
submenu that will appear in each of its yadnya categories, such as Upakara, Banten, Ulam, Uparengga, Dance, Tabuh and Mantra.
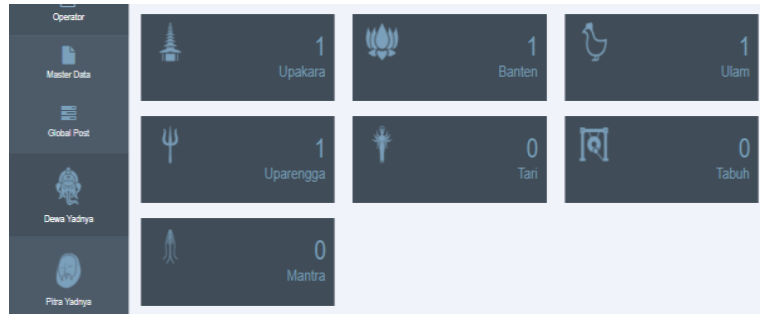

Figure 8. Example of Yadnya category in data management

Data Management feature as shown in Figure 8 is available at the main page of the EUpakara system, where the administrator can input the Upakara, Banten, Ulam, Uparengga, Tari (dance), Tabuh, and Mantra from each Yadnya category.

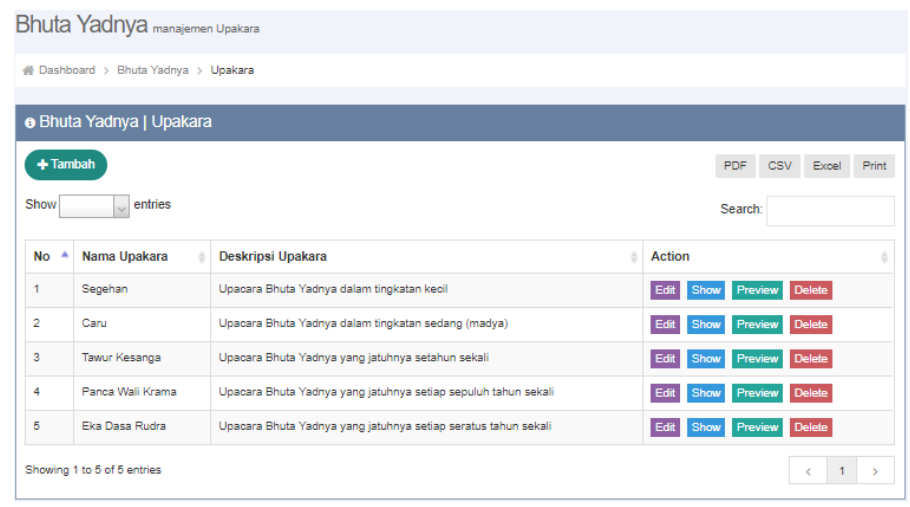

Figure 9. Data example in Bhuta Yadnya category

Figure 9 shows the example of upakara data that has been inserted into Bhuta Yadnya category, which is one of the Yadnya categories. This page shows the name of upakara, the description of upakara, and the actions that can be taken. 


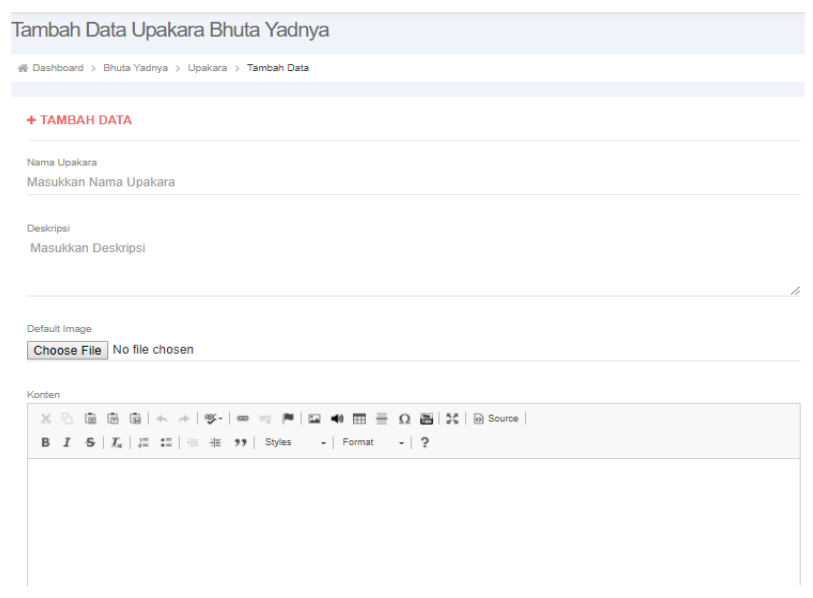

Figure 10. Add data form

Figure 10 shows Add Data form in E-Upakara information system. This form is used to add new Upakara data. Administrator can input the name of upakara, the description, the image of upakara, and content that explains the upakara. Inside the data content can be filled with additional links to refer to other information, photos, sound recordings, and videos that complete the contents of the information entered.
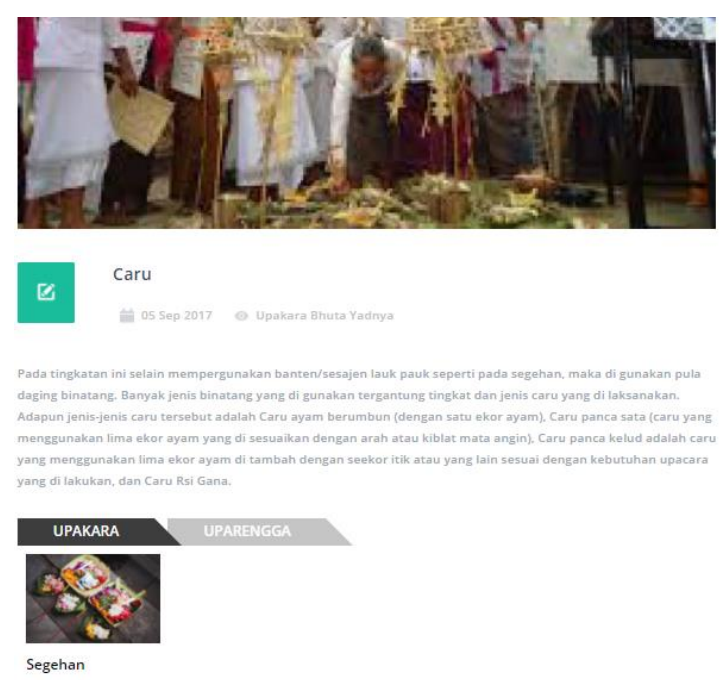

Figure 11. Upakara post detail

Figure 11 is the post detail on E-Upakara information system of an upakara as seen from the user, with Caru as upakara used in Bhuta Yadnya as an example. User is able to read more information regarding the post by clicking Read More from the main page. The user is able to read and find out if there's another upakara related to Upakara Caru after clicking the Read More button. Users can also find out about the uparengga needed in the upakara. If the user wants to read related post to Upakara Caru, the user can immediately select the desired post. The user can also share the 
post via social media such as Facebook, Twitter, and Google Plus by using the Share feature.

The E-Upakara information system can be accessed from both desktop and smartphone. Users are able to easily find out a specific upakara from a Yadnya ceremony based on the Yadnya category, and also understand other upakara used in the same Yadnya ceremony by looking at the related posts in the Upakara Post Detail page. The photos and videos of upakara in each post provide a look of how the upakara looks like and is made, which makes learning about upakara more interesting.

\section{CONCLUSION}

According to the testing results, it can be concluded that the E-Upakara information system can manage the information of bebantenan related to Yadnya ceremony by using tree modelling as the main model. E-Upakara provides information about the description, tools, ingredients, and how to make bebantenan in the form of text, photos, and videos. Bebantenan is modelized with tree diagram, because each bebantenan may have properties that can be symbolized until a certain level of depth. The properties of upakara/bebantenan are its group, description, and its relation to Yadnya ceremony, where these properties can be applied to all kinds of Yadnya ceremony. The user interface of E-Upakara information system can be improved to make it more appealing to users, since the current user interface is still quite simple. Future researches on bebantenan information system can combine the multimedia files used in E-Upakara with three-dimensional augmented reality applications related to bebantenan to make learning about bebantenan more interactive.

\section{REFERENCES}

[1] Ari Pinatih, I. G. B., Oka Sudana, A. A. K., \& Adi Purnawan, I. K. (2014). EBanjar Bali, Population Census Management Information System of Banjar in Bali by Using Family Tree Method and Balinese Culture Law. Journal of Theoretical and Applied Information Technology, 59(2), 411-420.

[2] Saputra, I. M. W., Sudana, A. A. K. O., \& Sukarsa, I. M. (2014). Implementasi Struktur Data Tree pada Sistem Informasi Upacara Yadnya Berbasis Android. Jurnal Ilmiah Merpati (Menara Penelitian Akademika Teknologi Informasi), 2(3), 326-334.

[3] Kompiang Oka Sudana, A. A., Purnawan, I. K. A., \& Dewi, N. M. R. M. (2014). Android Based Translator of Balinese into Indonesian using Binary Search Method. International Journal of Software Engineering and Its Applications, $8(6), 165-181$.

[4] Sudana, A. A. K. O., Yuniastari, N. L. A. K., \& Wirdiani, N. K. A. (2012). Implementasi Struktur Tree dan Metode Rekursif untuk Pemodelan Sistem Informasi Pitra Yadnya berbasis WEB. Seminar Nasional Informatika 2012 (pp. 289-295), Medan: STMIK Potensi Utama.

[5] Oka Sudana, A. A. K. (2011). Implementasi Struktur Tree pada Rancang Bangun Sistem Penelusuran Sejarah Pura Kawitan dan Kahyangan Jagat Berbasis Web. Lontar Komputer : Jurnal Ilmiah Teknologi Informasi, 2(1), 6982. 
[6] Oka Sudana, A. A. K., Kurnia Jayanti, I. A. (2011). Implementasi Struktur Tree untuk Pemodelan Sistem Informasi Bebantenan On-line dalam Upacara Yadnya Agama Hindu. Proceding Snatika 2011. Malang: APTIKOM.

[7] Oka Sudana, A. A. K., Putri, G.A.A., Suatini, I.A., Utari Dewi, I.A. (2010). Tree Data Structure Implementation in E-Learning Bebantenan On-line. Proceeding of ICSTD, Bali: Udayana University Press.

[8] Dewi, N. P. R. G., Sudana, O., \& Sukarsa, M. (2017). Implementasi Diagram Tree pada Rancang Bangun Sistem Informasi Bebayuhan Oton Berbasis Web. Lontar Komputer : Jurnal Ilmiah Teknologi Informasi, 8(3), 178-187.

[9] Sudana, A. A. K. O., Sukarsa, I. M., \& Saputra, I. M. W. (2014). Information System of Yadnya Ceremony on Android-Based. International Journal of Hybrid Information Technology, 7(6), 155-164.

[10] Sudana, A. A. K. O., \& Brampramana Putra, A. A. G. (2015). Tree Data Structure Implementation in Android Base System of E-Ulambebantenan. Applied Mechanics and Materials, 776, 431-436.

[11] Mahadewi, I. G. A. S. S., Sasmita, G. M. A., \& Wibawa, K. S. (2016). Aplikasi Animasi 3 Dimensi Mendem Ari-Ari Berbasis Android. Jurnal Ilmiah Merpati (Menara Penelitian Akademika Teknologi Informasi), 4(1), 114-122.

[12] Sudana, A. A. K. O., Ayu, R. R. S. S. W., \& Wirdiani, N. K. A. (2016). Instructional Learning Media to Create Upakara for Nyiramin Layon Procession based on Android. International Journal of Computer Applications, 144(10), $32-35$.

[13] Oka Sudana, A. A. K., Sujana, I. W. M., \& Rusjayanthi, N. K. D. (2017). ARBantenOtonan: A Learning Media Base on Augmented Reality Traditional Balinese Birthday Ceremony Equipment. Journal of Theoretical and Applied Information Technology, 95(7), 1362-1369. 